\title{
Malignus kevert Müller-cső-eredetü tumor komplex kezelése
}

\author{
Kalincsák Judit dr. ${ }^{1}$ - Gőcze Péter dr. ${ }^{1}$ - Bódis József dr. ${ }^{1}$ \\ Kovács Krisztina dr. ${ }^{2}$ - Stefanovits Ágnes dr. ${ }^{1}$ - Bohonyi Noémi dr. ${ }^{1}$ \\ Péntek Sándor dr. ${ }^{1}$ - Papp Szilárd dr. ${ }^{1}$
}

Pécsi Tudományegyetem, Általános Orvostudományi Kar, Klinikai Központ, ${ }^{1}$ Szülészeti és Nőgyógyászati Klinika, Onkológiai Osztály, ${ }^{2}$ Pathologiai Intézet, Pécs

\begin{abstract}
Bevezetés és célkitüzés: A közlemény célja ismertetni a méhdaganatok egy meglehetősen ritka, klinikailag igen agresszív típusának, a malignus kevert Müller-cső-eredetű daganatnak, más néven carcinosarcomának a jellegzetes prognosztikai faktorait, kezelésének lehetőségeit.

Módszer: 2009 és 2017 között 29 beteget kezeltünk malignus Müller-cső-eredetű tumor miatt. I. stádium esetén mútétet és posztoperatív sugárkezelést végeztünk. II-IV. stádium esetén trimodális kezelés történt (mütét, kemoterápia és sugárkezelés).

Eredmények: A betegek átlagéletkora 68,51 (49-90) év, átlagos BMI: 30,22 (20,90-37,22). Komplett reszekció utáni recidívát 6 esetben diagnosztizáltunk (ebból 4 beteg nem fogadta el a sugárkezelést), átlagosan 15,52 (6-36) hónap elteltével, távoli metasztázist 5 esetben, átlagosan 19,2 (8-32) hónap múlva. A teljes túlélés átlag 11,92 hónap (1-75). Hat beteg jelenleg is daganatmentes.

Következtetések: Jelenleg nincs egységes konszenzus a daganat terápiás ellátására vonatkozóan. A kezelésben standard a mütéti eljárás, mely teljes hasi méheltávolítást és kétoldali adnexectomiát jelent, azonban a helyi recidívák és távoli metasztázisok nagy előfordulási aránya miatt felmerült a regionális nyirokcsomó-eltávolítás és posztoperatív kezelés szükségessége. Bár a posztoperatív sugárkezelés a lokoregionális kontrollt javítja, túlélésre vonatkoztatott előnye továbbra sem bizonyított. Az adjuváns kemoterápia mind a kismedencei, mind az extrapelvicus recidívák arányát csökkenti, azonban továbbra sincs egyértelmű ajánlás a leghatékonyabb kemoterápiás szerre vonatkozóan. A teljes túlélést kombinált citosztatikus kezeléssel sem sikerült javítani az elmúlt évtizedekben, ezért azt gondoljuk, hogy a multimodális kezeléstől várhatók jobb eredmények. A hatékonyabb ellátás céljából - az onkológia más területeihez hasonlóan - biológiai terápiával és target kezeléssel kapcsolatban is folynak vizsgálatok; az alacsony betegszám miatt releváns következtetés csak hosszú évek múlva vonható le.
\end{abstract}

Orv Hetil. 2018; 159(19): 741-747.

Kulcsszavak: uterussarcoma, malignus kevert Müller-cső-eredetű tumor, lymphadenectomia, adjuváns kezelés

\section{Multimodal treatment of malignant mixed Müllerian tumor}

Introduction and aim: The aim of our study was to evaluate the prognostic factors and treatment options of a very rare and highly aggressive type of uterine neoplasms, the malignant mixed Müllerian tumor, known as carcinosarcoma. Method: Between 2009 and 2017, 29 patients were treated with malignant mixed Müllerian tumor. At stage I, surgery and postoperative radiotherapy were performed. At stages II-IV, trimodal treatment (surgery, chemotherapy and radiotherapy) was administered.

Results: The average age of patients was 68.51 (49-90) years, mean body mass index was 30.22 (20.90-37.22). We have experienced recurrence of disease after complete resection in 6 cases ( 4 of 6 patients did not accept radiation therapy). Local recurrence has occurred after an average 15.52 (6-36) months, distant metastasis with an average 19.2 (8-32) months. Overall survival was 11.92 (1-75) months. Six patients are free of tumours at the moment. Conclusions: As overall survival has not increased in recent decades by using combined chemotherapy, there is no congruent consensus associated with the optimal treatment. The standard surgical treatment is total abdominal hysterectomy with bilateral oophorectomy, although due to high rates of recurrence and metastases, the necessity of lymphadenectomy and postoperative treatment is in the focus of recent studies. Though postoperative irradiation improves local control, the beneficial effect on overall survival is still not proven. Adjuvant chemotherapy decreases the rate of both pelvic and extrapelvic recurrence at the same time, although there is no recommendation for the optimal chemoterapeutic agent. Multimodal therapy should lead to better outcomes. Recently there are many ongoing studies with biologic and target therapies to improve efficiency, however, the relevant results will be disclosed in many years only, due to the small number of patients. 
Keywords: uterus sarcoma, malignant mixed Müllerian tumor, lymphadenectomy, adjuvant treatment

Kalincsák J, Gőcze P, Bódis J, Kovács K, Stefanovits Á, Bohonyi N, Péntek S, Papp Sz. [Multimodal treatment of malignant mixed Müllerian tumor]. Orv Hetil. 2018; 159(19): 741-7747.

(Beérkezett: 2018. január 3.; elfogadva: 2018. február 10.)

\begin{abstract}
Rövidítések
$\mathrm{BMI}=($ body mass index $)$ testtömegindex; $\mathrm{BSO}=$ bilateralis salpingo-oophorectomia; $\mathrm{CAP}=$ doxorubicin-ciszplatinciklofoszfamid; $\mathrm{CK}=$ citokeratin; $\mathrm{CT}$ = komputertomográfia; DFS $=($ disease-free survival $)$ betegségmentes túlélés; EGFR = (epidermal growth factor receptor) epidermális növekedési faktor receptor; EMA = epithelialis membránantigén; FIGO = (International Federation of Gynecology and Obstetrics) Nemzetközi Nógyógyászati és Szülészeti Szövetség; GOG = (Gynecologic Oncology Group) Amerikai Nőgyógyászati Onkológiai Munkacsoport; HER2 = humán epidermális növekedési faktor receptor 2-es típusa; KRAS = Kirsten Rat Sarcoma fehérje; MMMT = (malignant mixed Müllerian tumor $)$ malignus kevert Müller-cső-eredetű daganat; $\mathrm{MR}=$ mágneses rezonancia; $\mathrm{NCCN}=$ (National Comprehensive Cancer Network $)$ Amerikai Nemzeti Átfogó Onkológiai Hálózat; OS = (overall survival) teljes túlélés; PARP = poli-(ADP-ribóz)-polimeráz; $\mathrm{PET} / \mathrm{CT}=$ pozitronemissziós tomográfia CT-vizsgálattal; PFS $=$ (progression-free survival) progressziómentes túlélés; PI3K = foszfatidilinozitol 3-kináz; PTEN = (phosphosphatase and tensin) foszfatáz és tenzin tumor szuppresszor fehérje; $\mathrm{RT}=($ radiotherapy $)$ sugárkezelés; SUV $=($ Standardized Uptake Value) standard felvételi hányados; $\mathrm{TAH}=$ totális abdominalis hysterectomia; VEGF $=($ vascular endothelial growth factor) vascularis endothelialis növekedési faktor
\end{abstract}

A malignus kevert Müller-cső-eredetű daganat (MMMT), más néven carcinosarcoma, rendkívül ritka és igen agresszív típus az uteruscarcinomák között, előfordulása körülbelül $5 \%$, incidenciája az életkorral növekszik. A tumor valószínúleg az uterus endometriumának epithelsejtjeiból származik, de a pontos patogenezis továbbra is tisztázatlan. Genetikáját, immunfenotípusát, klinikai viselkedését és hasonló rizikófaktorait tekintve a high grade endometriumcarcinomákkal - mint a serosus, világos sejtes és differenciálatlan endometriumdaganat mutat hasonlóságot, melyek alacsony ösztrogénszinttel jellemezhetők [1]. Lokalizációját tekintve a leggyakrabban az uterusban, ritkábban a vaginában, a cervixben, az ovariumban, valamint a tubákban is előfordulhat [2]. A tumor típusosan postmenopausalis nókben észlelhető, átlag 65 éves életkorban; fiatal nőkben extrém ritka. Felismerésére postmenopausalis vérzés, kismedencei terime, hasi diszkomfortérzés, atípusos citológiai lelet, ascites hívhatja fel a figyelmet. Ezek közül a leggyakoribb „tünettriád” a fájdalom, súlyos vérzés és vaginán keresztül távozó nekrotikus szövettörmelék. A daganat a felfedezéskor az esetek több mint felében már előrehaladott stádiumban van. A rizikófaktorok közül megemlítendő a nulliparitás, az idősebb életkor, az obesitas, a hypertensio, a diabetes, az exogén ösztrogénbevitel, a tamoxifen hosszú távú alkalmazása, korábbi kismedencei sugárkezelés, ugyanakkor egyik sem specifikus [3]. Carcinosarcoma esetén az anamnézisben egyes felmérések szerint 5-30\%-ban fordul elő sugárkezelés; a betegség kialakulását átlagosan 14 éves latenciaperiódus előzi meg [4]. A tamoxifen etiológiai szerepére vonatkozóan több publikáció is megjelent. Hormonreszponzív invazív és in situ emlőcarcinomában a kedvező antiösztrogén-hatását használjuk ki, az uterusban azonban ösztrogéneffektusa van, így a hosszú távú tamoxifenalkalmazás szerepet játszhat az endometriumadenocarcinoma és az MMMT patogenezisében. A relatív rizikó MMMT kialakulására magasabb, mint endometriumadenocarcinoma kifejlődésére [5]. Ezzel szemben oralis fogamzásgátlók védőszerepét feltételezik [6]. Az MMMT öröklődő betegségekkel való asszociációja nem bizonyított, habár Lynch-szindróma esetében összefüggés feltételezhető uteruscarcinomák kialakulásával.

Hisztológiáját tekintve a daganatban malignus hámés mesenchymalis komponensek észlelhetők. A daganat fénymikroszkópos képe meglehetősen sokszínű: a hámelemek között a legnagyobb gyakorisággal endometrioid, serosus és világos sejtes endometriumcarcinoma fordul elő, míg a mesenchymalis komponensek között a legkülönfélébb sarcomaszubtípusokkal találkozhatunk. A sarcomatosus komponens alapján a daganatok tovább kategorizálhatók heterológ és homológ típusokra. A heterológ típusban rhabdomyosarcoma, chondrosarcoma, osteosarcoma vagy liposarcoma elemeit láthatjuk, a homológban alacsony vagy magas grádusú endometrialis stromalis sarcoma, leiomyosarcoma, és/vagy differenciálatlan endometriumsarcoma része fordulhat elő [7]. Immunhisztokémiailag ugyancsak igen változatos profillal találkozhatunk. A tumor bifázisos jellegéból adódóan hám- és mesenchymalis markerekkel az egyes komponensek elkülöníthetők, azonban EMA-, CK- és vimentinpozitivitás mellett pl6-, p53-pozitivitás mindkét komponens sejtjeiben megjelenhet. Az immunhisztokémiai és a molekuláris genetikai vizsgálatok szerint a sokirányú differenciáció ellenére az elváltozás monoklonálisnak bizonyul [1]. Molekuláris genetikai hátterét tekintve az X-kromoszóma inaktivációjával kapcsolatban történtek vizsgálatok. Wada és mtsai mind az epithelialis, mind a mesenchymalis komponens tekintetében találtak p53- és KRAS-mutációt, ami szintén a monoklonális eredetet valószínúsíti [8]. Polimorfikus mikroszatellita 
markereket vizsgálva allélvesztés található mindkét komponensben. A monoklonális eredetet valószínúsíti, hogy a carcinosarcoma metaplasztikus transzformációval jön létre. Cherniack és mtsai molekuláris genetikai, epigenetikai és transzkripciós vizsgálatokat végeztek carcinosarcomával kapcsolatban. Molekuláris genetikai hátterét tekintve MMMT esetén gyakran található TP53-, PTEN-, PI3K-és KRAS-mutáció, csakúgy, mint az endometrioid és serosus carcinomákban. Transzkripciós szekvenálás során carcinosarcomában egy erôs epithelialis-mesenchymalis tranzíciós gén jelét azonosították, amely a mikro-RNS-promóterek epigenetikus változásainak tulajdonítható. Úgy gondolják, hogy a metaplasztikus átalakulás ennek az erős jelnek a következtében jön létre. Többszörös szomatikus mutációkat és számbeli eltéréseket is találtak, amelyek célzott terápiás lehetőségeket kínálnak a PARP-, sejtciklus- és PI3K-útvonal-inhibitorok lehetséges alkalmazásának [9].

\section{Célkitüzés}

A vizsgálat célja a különböző diagnosztikai módszerek, terápiás modalitások megismertetése és hatékonyságainak összehasonlítása a szakirodalomban közölt eredményekkel, valamint saját beteganyagunk ismertetése.

\section{Diagnózis}

Preoperatív staging tekintetében az endometriumtumoroknál korábban széles körben alkalmazott CT-vizsgálat jelenleg már nem elégséges a pontos stádium meghatározásához. Informatívabb a kismedence-MR [10], illetve a teljes test ${ }^{18} \mathrm{~F}$-FDG PET/CT vizsgálata, mely a nyirokcsomó-eltávolítás szükségességének megítélésében is meghatározó. Az MR-képek összevetése a mütét utáni szövettani eredménnyel megerősítette, hogy a T1-T2 súlyozott intenzitások endometriumcarcinoma és MMMT esetén $88 \%$-ban azonosak, vagyis önmagában az MR-kép alapján a két entitást nem lehet megkülönböztetni [11]. Endometriumtumorok differenciálására a $\mathrm{PET} / \mathrm{CT}$ vizsgálat sem alkalmas, hiszen az uteruscarcinosarcoma és egyéb corpuscarcinomák átlag SUVmaxértéke egymáshoz közeli $(9,5$ vs. átlag 7,5-8,8) [12]. Primer tumor tekintetében a két különböző vizsgálati eljárás nem mutat statisztikai szignifikáns különbséget szenzitivitásban és specificitásban. A PET/CT és az MRvizsgálat azonos mértékben valószínúsíti a myometrium invázióját és a cevix involváltságát, míg nyirokcsomómetasztázis kimutatásában a PET/CT jobbnak bizonyult [13]. Az extrauterin metasztázisokra fókuszálva a PET/CT vizsgálat bizonyult magas specificitásúnak és pontosságúnak. Túlélésjavító hatását észlelték, a korábban felfedezett, kisméretű metasztázisok, illetve recidívák észlelése következtében korán megkezdett kemoterápia eredményeképpen. A pontos diagnózis felállításában curette/biopszia végzése elengedhetetlen. Az MMMT diagnózisának megerősítése, illetve végleges szövettani eredmény és a patológiai stádium meghatározása azonban csak a teljes mútéti preparátum feldolgozásától várható. A tumormarkerek közül a CA125 általában emelkedett, ami korrelál a myometriuminvázió mélységével, utalhat az extrauterin terjedésre, és mortalitás tekintetében is prognosztikus jelentőséggel bír [14]. Stádiumbesorolása megegyezik az endometriumdaganatok FIGO-osztályozásával.

\section{Mütét}

Jellemzően már korai stádiumban is metasztatikus, így ennél az agresszív tumortípusnál, más endometriumcarcinomával ellentétben, fertilitásmegőrző terápia nem javasolt még nagyon korai stádiumban sem. Az MMMT-t metaplasiás carcinomának tekinti a szakirodalom, sebészi kezelése megegyezik a rossz prognózisú endometriumcarcinoma (serosus papillaris és clear cell) kezelésével [15]. Reszekábilis esetben ellátása totális abdominalis hysterectomia (TAH), bilateralis salpingo-oophorectomia (BSO), peritonealis lavage citológiai vizsgálathoz, cseplesz- és peritonealis biopszia. Törekedni kell a maximális tumordebulkingra [16]. Amennyiben technikailag lehetséges, minimálinvazív sebészet a preferálandó eljárás. A lymphadenectomia hasznos lehet a pontos patológiai staging felállításában, a lokoregionális recidíva csökkentésében, a megfelelő betegszelekcióban az adjuváns kezelés megválasztásához, valamint túlélésbeli előnyt is hoz [17]. Garg és mtsai a halálozási ráta rizikójának 33\%os csökkenését észlelték lymphadenectomia elvégzése esetén, összehasonlítva annak elhagyásával [18]. Nemani és mtsai ezzel megegyezően szintén előnyt észleltek az 5 éves medián teljes túlélésben (54 hó vs. 25 hó) [19]. Horváth és mtsai grade 3, valamint magas rizikójú seropapillaris és clear cell endometriumcarcinomák esetén minden esetben javasolják lymphadenectomia elvégzését. Mivel a carcinosarcoma ezen tumortípusokkal mutat biológiai hasonlóságot, talán MMMT esetén is ajánlható lenne a lymphadenectomia elvégzése [20].

\section{Kemoterápia}

A kemoterápiának fontos szerepe van mind a lokális, mind a távoli áttétek rizikójának csökkentésében [21]. A dominánsan carcinomatosus elemeket tartalmazó tumor esetén jobb teljesválasz-ráta $(87,5 \%)$ érhető el, szemben a sarcomatosus komponens dominanciájának esetével [22]. A National Comprehensive Cancer Network (NCCN) már korai stádiumban is ajánlja az adjuváns terápia adását. Szoros megfigyelést csak IA stádiumban javasol abban az esetben, ha a mútéti preparátumban nincs residualis serosus vagy világos sejtes komponens. Egyebekben még ebben a korai stádiumban is adjuváns kemoterápiát vagy kismedencei sugárkezelést javasol kiegészítve hüvelyi brachytherapiával, elsődlegesen azonban a kemoterápia választását preferálja. Korai stádiumú MMMT esetén adott posztoperatív kemoterápia jobb 
progressziómentes túlélést mutat az obszerváció, illetve a posztoperatív radioterápia adásához képest. Mint a hasonló viselkedésû serosus papillaris endometriumcarcinománál, Langmár és mtsai is arra a következtetésre jutottak vizsgálatukban az NCCN-ajánlással megegyezően, hogy csak IA stádium esetén hagyható el az adjuváns kezelés [23]. IB stádiumtól kezdődően az NCCN minden esetben adjuváns kemoterápiát tart szükségesnek esetleges pelvicus és hüvelyi sugárkezeléssel kiegészítve. Korábbi vizsgálatok az egyedüli ágensként adott ifoszfamid adását erősítették, mellyel 18-36\%-os válaszráta volt elérhető [21]. A GOG (Gynecologic Oncology Group) vizsgálatai során egyéb kemoterápiás szer ifoszfamiddal együtt történő adását vizsgálták. A GOG 108-as vizsgálat az egyedüli ifoszfamid és az ifoszfamid-ciszplatin kombinációt hasonlította össze, míg a GOG 161-es vizsgálat az egyedüli ifoszfamid és az ifoszfamid-paclitaxel kombinációt. Mindegyik vizsgálati karon a kombinált kezelések hoztak jobb válaszarányt és magasabb progressziómentes túlélést (PFS), bár a teljes túlélésben (OS) csak az ifoszfamid-paclitaxel hozott jobb eredményeket az ifoszfamid egyedüli alkalmazásához képest (13,5 hó vs. 8,4 hó) $[24,25]$. Előrehaladott stádiumú carcinosarcomát vizsgáló fázis III vizsgálat szintén az ifoszfamidpaclitaxel kombináció alkalmazását mérte fel. Alacsonyabb volt a toxicitása, valamint túlélésbeli elönyt is mutatott a korábban használt ifoszfamid-ciszplatin regimenhez képest [24]. Fázis II vizsgálat alapján a paclitaxel-karboplatin kombináció közel ugyanolyan hatékonynak bizonyult carcinosarcomában (válaszráta 54\%) [21]. Jobb PFS és OS érhető el, valamint jobb hatékonyság tapasztalható a kompletten reszekált, egyedüli adjuváns sugárkezelést kapó betegcsoporthoz képest. A jelenleg is zajló GOG 261-es vizsgálat az I-IV. stádiumban adott paclitaxel-karboplatin vs. paclitaxel-ifoszfamid kombinációt hasonlítja össze, előzetes eredményei a karboplatinpaclitaxel kombináció hatékonyságát erősítik nemcsak előrehaladott és recidiváló esetben alkalmazva, hanem adjuváns kezelésként is. A végleges eredményekre még várni kell. Újabban a centrumokban taxán-platina alapú kezeléseket végeznek világszerte.

\section{Sugárkezelés}

Korábbi leírásokban az MMMT mütéti ellátásának általános kiegészítőjeként szerepelt a sugárkezelés mind pre-, mind posztoperatív indikációban. Recidiváló, illetve metasztatikus esetben a teljes hasi/abdominopelvicus besugárzást javasolták brachytherapiás dóziskiegészítéssel, azonban a tapasztalt magas korai és késői toxicitásprofil miatt rutinszerű adását jelenleg nem preferálják, még a sugárterápiában bekövetkezett jelentős technikai fejlődés (intenzitásmodulált és képvezérelt radioterápia) [26] következtében javuló mellékhatásprofilt figyelembe véve sem. A kismedencei recidíva okozta morbiditás nem elhanyagolható, így észszerü a lokoregionális kontroll emelése céljából MMMT esetén a posztoperatív sugárke- zelés megajánlása. Több vizsgálat is bizonyította a posztoperatív irradiáció eredményességét, foóleg a lokális kontroll szempontjából, bár a teljes túlélés tekintetében az eredmények már kevésbé kecsegtetőek. Az adjuváns kismedencei sugárkezelés csökkenti a helyi kiújulás arányát az egyedüli mütéti megoldáshoz képest. Bizonyos esetekben a jobb lokális kontroll korrelál a túlélésbeli előnynyel, azonban felmérések alapján a lymphadenectomia elvégzése még mindig nagyobb hasznot hoz az irradiációhoz képest. A távoli metasztázis kialakulásának aránya adjuváns kismedencei irradiáció alkalmazása és elhagyása esetén közel azonos (35\%). Standard dózisra ajánlat továbbra sincs, azonban konvencionális frakcionálással legalább 50 Gy adása indokolt. A carcinosarcomát Póti és $m t s a i$ is a magas kockázati csoportba sorolják az endometriumtumorok között. Amennyiben nyirokcsomódissectio után pN0 státusz igazolódik, az adjuváns kismedencei irradiációt megfontolandónak tekintik a lokoregionális kiújulás csökkentése céljából (I. B evidencia), de alternatívaként adjuváns brachytherapia is adható, a hüvelyi recidívák kialakulásának csökkentésére (III. evidencia). Ha sebészeti staging nem történt, akkor az adjuváns külső besugárzás többnyire szükséges (II. C evidencia) a kiújulásmentes túlélés növelése céljából (III. B evidencia) [27]. A paraaorticus régió sugárkezelése csak egyértelmúen igazolt érintettség esetén indokolt [28]. Inoperábilis/irreszekábilis esetben definitív sugárkezelés minden esetben javasolt (2. A evidencia) hüvelyi brachytherapiával kiegészítve és szisztémás kezelés alkalmazásával. A sugárkezelés kemoterápiával kiegészítve hatékonyabbnak tünik az egyedül alkalmazott sugárkezeléshez képest. A szekvenciálisan adott adjuváns kemoterápia megfontolandó a PFS és a daganatspecifikus túlélés javítása céljából (II. C evidencia). Egyre több bizonyíték támasztja alá a sugárkezelés és a kemoterápia együttes adásának előnyét, szemben azzal, ha a terápiás modalitás közül a beteg csak az egyikben részesül. Palliatív esetekben (fájdalom, vérzés) sugárkezeléssel a tünetek enyhíthetők.

\section{Biológiai/target terápia}

Tekintettel a kemoterápiás kezeléssel elérhető alacsony válaszrátára $(30 \%)$, valamint arra a tényre, hogy másodvonali kezelés után alkalmazott egyéb kemoterápiás kombinációk effektivitása is csupán 5-10\%, egyéb gyógyszer-kombinációk alkalmazásának kipróbálására van szükség. Immunhisztokémiailag jellegzetes a HER2-, EGFR- és VEGF-overexpresszió, ezen útvonalak gátlása lehetséges a target terápiák során. Iniparib karboplatinpaclitaxellel történő kombinációjával kapcsolatban a felmérés szignifikáns eredményt nem hozott [29]. Egyedüli szunitinib adásával kapcsolatban Castonguay és mtsai végeztek vizsgálatot, recidiváló vagy metasztatikus endometriumcarcinoma és carcinosarcoma esetén. Ígéretes eredményeket találtak betegségkontroll szempontjából, így azt feltételezik, hogy az angiogenezis útvonalának 
gátlása megfelelő célpont lehet további kezelés szempontjából [30]. Recidiváló vagy metasztatikus carcinosarcoma esetén VEGF-gátló aflibercepttel kapcsolatban is végeztek vizsgálatot, azonban megfelelő válaszráta hiányában a vizsgálati kart bezárták [31].

\section{Kombinált kezelés}

Bár az utóbbi évtizedekben jelentős fejlődés történt az adjuváns kezelésekkel kapcsolatban, szignifikáns túlélésbeli növekedést nem tapasztaltunk. Az MMMT elsődleges ellátása továbbra is sebészi, azonban posztoperatív ellátásként mind a kemoterápiát, mind a sugárkezelést javasolják. A szekvenciálisan alkalmazott kezelés nemcsak kevesebb toxicitással, hanem 50-80\%-os mortalitáscsökkenéssel jár az egyedüli adjuváns sugárkezelés vagy kemoterápia alkalmazásához képest [32]. A multimodális kezelés előnyeit több, nem randomizált vizsgálat is elemezte. Einstein és mtsai négykarú vizsgálatot végeztek: obszerváció, egyedüli sugárkezelés (RT), egyedüli kemoterápia $(\mathrm{CT})$ és kombinált kemoterápia-sugárkezelés $(\mathrm{CT}+\mathrm{RT})$ [33]. A sarcomák esetén használatos szendvicsprotokoll (kemoterápiás ciklusok között alkalmazott sugárkezelés) esetén találtak kedvező kimenetelt, III-IV. stádiumban jobb betegségmentes túlélés (DFS) érhetó el a többi kezelési opcióhoz képest (obszerváció, egyedüli sugárkezelés, egyedüli kemoterápia). I-II. stádiumban az obszerváció vizsgálati karon négyszeresére emelkedett a halálozási ráta az adjuvánsan kemoterápiát kapó csoporthoz képest. A CT + RT csoportban szignifikánsan magasabb progressziómentes túlélés volt elérhetô az egyedüli CT alkalmazásához képest, bár hátrányként említik ebben az esetben a multimodális kezelés okozta erősebb toxicitásból adódó életminőség-romlást, valamint a teljes túlélés emelkedésének hiányát. Korai stádiumban a tumorresiduum és a II. stádium önmagában rosszabb kimenetelt jelent, előrehaladott stádiumban pedig a lymphovascularis invázió a prognosztikus. A radioterápiát kapó csoportokban a recidívák extrapelvicusan jelentkeztek, míg a kemoterápia karon elsősorban a kismedencén belül. A GOG 150-es fázis III klinikai vizsgálata ciszplatin-ifoszfamid vs. teljes hasi sugárkezelés összehasonlítása során a mortalitási ráta csökkenését észlelte kemoterápia alkalmazásakor optimálisan reszekált I-IV. stádiumú MMMT esetén, bár statisztikai szignifikanciát nem ért el az eredmény [34].

\section{Betegek}

A PTE KK Szülészeti és Nőgyógyászati Klinikáján 2009 és 2017 között 29 beteg ellátása történt MMMT miatt, minden esetben frakcionált curette erősítette meg a malignus diagnózist. Négy egyéb esetben is carcinosarcomát igazolt a preoperatív curette, azonban a posztoperatív minta feldolgozása végeredményben endometriumadenocarcinomát véleményezett. Végleges szövettani meghatározás csak a hysterectomia utáni teljes prepará-
1. táblázat |Anamnesztikus adatok

\begin{tabular}{lcc}
\hline Betegadatok & Esetszám & Százalékos arány \\
\hline Hypertonia & 13 & $44,88 \%$ \\
Diabetes & 13 & $44,88 \%$ \\
Megelőző tamoxifenkezelés & 3 & $10,34 \%$ \\
Korábbi kismedencei sugárkezelés & 3 & $10,34 \%$ \\
Emelkedett CA125-érték & 11 & $37,93 \%$ \\
Primer tumor a méhtestben & 26 & $89,65 \%$ \\
Primer tumor a petefészekben & 2 & $6,89 \%$ \\
Primer tumor a hüvelyben & 1 & $3,44 \%$ \\
\hline
\end{tabular}

tum feldolgozásától várható, hiszen a curette során nem biztos, hogy minden szövettani elem belekerül a vizsgálandó mintába.

\section{Eredmények}

A betegek átlagéletkora 68,51 (49-90) év, átlagos BMI: $30,22(20,90-37,22) .13(44,88 \%)$ beteg anamnézisében szerepelt hypertonia és diabetes. Méhtestből 26 esetben, petefészekből 2 esetben, hüvelyből pedig 1 esetben indult ki a daganat. Három beteg korábban rectumtumor miatt kismedencei irradiációban részesült (átlag 9,33 évvel korábban). Emlőtumor miatt 3 beteg korábban tamoxifenkezelésben részesült. Emelkedett CAl25-értéket 11 esetben $(37,93 \%)$ észleltünk, mindegyiket a IV. stádiumban (1. táblázat). A mútétet minden esetben staging céljából kismedence-MR-vizsgálat előzte meg, melynek eredménye alapján a következő stádiummegoszlást észleltük (1. ábra). I. stádium: 4 beteg (13,79\%), II. stádium: 6 beteg (20,68\%), III. stádium: 8 beteg $(27,58 \%)$, IV. stádium: 11 beteg $(37,93 \%) .6$ esetben nem történt mútét rossz általános állapot és társbetegség miatt. 4 esetben csak exploratív laparotomia volt kivitelezhető, 11 esetben TAH + BSO hasi mosófolyadék vizsgálatával, 7 esetben TAH + BSO hasi mosófolyadék vizsgálatával és lymphadenectomiával kiegészítve, a hüvelybő́l kiinduló tumor esetén pedig csak hüvelyi excisio történt.

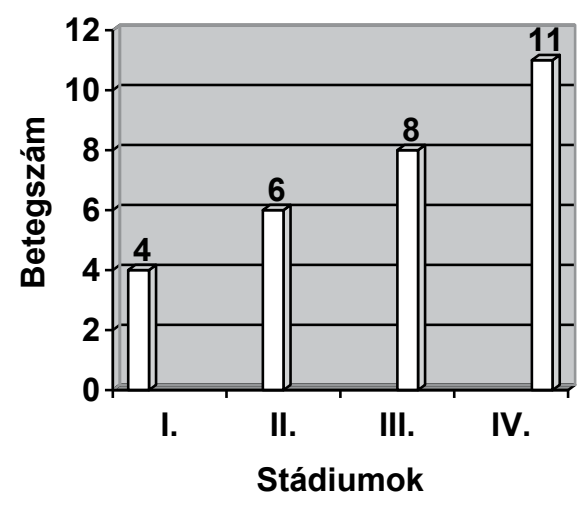

1. ábra $\quad$ A betegszám stádium szerinti megoszlása 
Az I. A stádiummal diagnosztizált 4 betegnél posztoperatív külső és belső sugárkezelést javasoltunk. II-IV. stádium esetén ( 25 beteg) kemoterápia és sugárkezelés mellett döntött az onkoteam. 6 beteg nem egyezett bele utókezelésbe. 13 esetben taxol-karboplatin kezelés történt, 5 esetben doxorubicin-ciszplatin-ciklofoszfamid (CAP), 1 esetben egyedüli ifoszfamid adása. Sugárkezelés esetén teljes kismedencei sugárkezelés történt brachytherapiával kiegészítve. Korábbi végbéldaganat irradiációja miatt 3 beteg csak brachytherapiában részesülhetett, sajnos mindhárom esetben röviddel a kezelés után (átlag 5,3 hónap) recidíva igazolódott. Komplett reszekció utáni recidívát 6 esetben diagnosztizáltunk (ebből 4 beteg nem fogadta el a sugárkezelést), átlagosan 15,52 (6-36) hónap elteltével, távoli metasztázist 5 esetben, átlagosan 19,2 (8-32) hónap múlva. A teljes túlélés átlag $11,92(1-75)$ hónap. Hat beteg jelenleg is daganatmentes.

\section{Következtetések}

A malignus kevert Müller-cső-eredetű tumor rendkívül ritka, igen agresszív elváltozás az endometrium rosszindulatú daganatai között. Diagnosztikus megerősítésében tapasztalt patológus nyújthat segítséget. Preoperatív kismedence-MR-vizsgálat minden esetben szükséges. A mütét alapján meghatározott FIGO-stádium, valamint a myometriuminvázió mélysége a legfontosabb prognosztikai mutatók. Az emelkedett CA125 korrelál az előrehaladott stádiummal. A szakirodalomban egybehangzóan javasolt standard mütéti eljárás a teljes hasi méheltávolítás, kétoldali petefészek-eltávolítással, regionális lymphadenectomia, peritonealis mosófolyadék-mintavétel, cseplesz- és peritonealis biopszia. Mütét során a teljes citoredukcióra kell törekedni. Adjuváns terápia a nagyon korai stádiumtól eltekintve minden esetben indokolt, a legjobb eredmények kemoterápia és külső-belső sugárkezelés együttes alkalmazásával érhetők el. Az adjuváns kemoterápia mind a kismedencei, mind az extrapelvicus recidívák arányát csökkenti. A legújabb ajánlások elsősorban az ifoszfamid-paclitaxel és a paclitaxel-karboplatin kombináció adását javasolják, monoterápiában pedig ifoszfamidot. A neoadjuváns kemoterápia hatékonyságára vonatkozólag nincsenek megfelelő szintü bizonyítékok. Bár a posztoperatív sugárkezelés a lokoregionális kontrollt javítja, túlélési előnye továbbra sem bizonyított. Kiújult daganat esetében a megelőzően alkalmazott kezelések és a recidíva lokalizációja alapján lehet dönteni az alkalmazandó terápiáról. A szakirodalom alapján a teljes túlélést nem sikerült szignifikánsan javítani az elmúlt évtizedekben, ezért azt gondoljuk, hogy a multimodális kezeléstől várhatók jobb eredmények, amihez hozzájárulhat a sugárterápiában bekövetkezett jelentős technikai fejlődés is. Sajnos a carcinosarcoma idősebb életkorban való előfordulása az általános állapot és a komorbiditások miatt határt szab az optimális multimodális kezelés alkalmazásának. Mint az onkológia egyéb területein, biológi- ai terápiával és target kezeléssel kapcsolatban is folynak vizsgálatok a hatékonyabb ellátás érdekében, bár a kis populáció miatt releváns következtetés csak évtizedek múlva várható.

Anyagi támogatás: A szerzők anyagi támogatásban nem részesültek.

Szerzői munkamegosztás: K. J., G. P. az ötletadók és az adatgyüjtők; K. K. a patológiai részt írta, P. Sz. a lektorálásban vett részt; B. J. a beteganyaghoz történő hozzáférést biztosította; S. Á., B. N., P. S. az adatgyújtésben segített. A cikk végleges változatát valamennyi szerző elolvasta és jóváhagyta.

Érdekeltségek: A szerzőknek nincsenek érdekeltségeik.

\section{Irodalom}

[1] Paulin F, Somogyi A. Endometrium carcinoma. In: Kásler M. (ed.) The basics of oncology. [Endometriumcarcinoma. In: Kásler M. (szerk.) Az onkológia alapjai.] Medicina Könyvkiadó, Budapest, 2011; p. 691. [Hungarian]

[2] Ahuja A, Safaya R, Prakash G, et al. Primary mixed Mullerian tumor of the vagina - a case riport with review of the literature. Pathol Res Pract. 2011; 207: 253-255.

[3] Kuyumcuoğlu U, Kale A. Homologous type of malignant mixed Mullerian tumor of the uterus presenting as a cervical mass. J Chin Med Assoc. 2009; 72: 533-535.

[4] Doss LL, Llorens AS, Henriquez EM. Carcinosarcoma of the uterus: a 40-year experience from state Missouri. Gynecol Oncol. 1994; 18: 43-53.

[5] Curtis RE, Freedman DM, Sherman ME, et al. Risk of malignant mixed Mullerian tumors after tamoxifen therapy for breast cancer. J Natl Cancer Inst. 2004; 96: 70-74.

[6] Kernochan LE, Garcia RL. Carcinosarcomas (malignant mixed Mullerian tumor) of the uterus: advances in elucidation of biologic and clinical characteristics. J Natl Compr Canc Netw. 2009; 7: 550-557.

[7] Orosz Zs. Pathological diagnosis of endometrium carcinoma. In: Bodoky Gy, Kopper L. (eds.) Breast and gynecological oncology. [Endometrium tumorok pathológiai diagnosztikája. In: Bodoky Gy, Kopper L. (szerk.) Emlő- és nőgyógyászati onkológia.] Medicina Könyvkiadó, Budapest, 2012; pp. 228-229. [Hungarian]

[8] Wada H, Enomoto T, Fujita M, et al. Molecular evidence that most but not all carcinosarcomas of the uterus are combination tumors. Cancer Res. 1997; 57: 5379-5385.

[9] Cherniack AD, Shen H, Walter V, et al. Integrated molecular characterization of uterine carcinosarcoma. Cancer Cell 2017; 31: 411-423.

[10] Pete I, Gödény M, Tóth E, et al. Prediction of cervical infiltration in Stage II endometrial cancer by different preoperative evaluation techniques. Eur J Gynaecol Oncol. 2003; 24: 517522.

[11] Lee HJ, Park JY, Lee JJ, et al. Comparison of MRI and ${ }^{18}$ F-FDG $\mathrm{PET} / \mathrm{CT}$ in preoperative evaluation of uterine carcinosarcoma. Gynecol Oncol. 2016; 140: 409-414.

[12] Lerman H, Metser U, Grisaru D, et al. Normal and abnormal ${ }^{18} \mathrm{~F}-\mathrm{FDG}$ endometrial and ovarian uptake in pre- and postmenopausal patients: assesment by PET/CT. J Nucl Med. 2004; 45: 266-271.

[13] Horváth K, Gödény M. New opportunities, MRI biomarkers in the evaluation of gynaecological cancer. [Új lehetôségek, MRI- 
biomarkerek a nőgyógyászati daganatok értékelésében.] Magy Onkol. 2015; 59: 216-227. [Hungarian]

[14] Huang GS, Chiu LG, Gebb JS, et al. Serum CAl25 predicts extrauterine disease and survival in uterine carcinosarcoma. Gynecol Oncol. 2007; 107: 513-517.

[15] Nechushkina V. Surgical treatment of endometrium carcinoma. In: Bodoky Gy, Kopper L. (eds.) Breast and gynecological oncology. [Endometrium tumorok sebészi kezelése. In: Bodoky Gy, Kopper L. (szerk.) Emlő- és nőgyógyászati onkológia.] Medicina Könyvkiadó, Budapest, 2012; p. 244. [Hungarian]

[16] Koh WJ, Abu-Rustum NR, Bean S, et al. Uterine Neoplasms, Version 1.2018, NCCN Clinical Practice Guidelines in Oncology. J Natl Compr Canc Netw 2018; 16: 170-199.

[17] Vorgias G, Fotiou S. The role of lymphadenectomy in uterine carcinosarcomas (malignant mixed Mullerian tumours): a critical literature review. Arch Gynecol Obstet. 2010; 282: 659-664.

[18] Garg G, Shah JP, Kumar S, et al. Ovarian and uterine carcinosarcomas: a comparative analysis of prognostic variables and survival outcomes. Int J Gynecol Cancer 2010; 20: 888-894.

[19] Nemani D, Mitra M, Guo M, et al. Assessing the effects of lymphadenectomy and radiation therapy in patients with uterine carcinosarcoma: a SEER analysis. Gynecol Oncol. 2008; 111: 8288.

[20] Horváth K, Pete I, Vereczkey I, et al. Evaluation of the accuracy of preoperative MRI in measuring myometrial infiltration in endometrial carcinoma. Pathol Oncol Res. 2014; 20: 327-333.

[21] Powell MA, Filiaci V, Rose PG, et al. Phase II evaluation of paclitaxel and carboplatin in the treatment of carcinosarcoma of the uterus: a Gynecologic Oncology Group study. J Clin Oncol. 2010; 28: 2727-2731.

[22] Ozguroglu M, Bilici A, Ilvan S, et al. Determining predominating histologic component in malignant mixed Müllerian tumors: is it worth it? Int J Gynecol Cancer 2008; 18: 809-812.

[23] Langmár Z, Németh M, Kornya L. Uterine papillary serous carcinoma. [A méhtest seropapillaris rákja.] Orv Hetil. 2011; 152: 1206-1208. [Hungarian]

[24] Homesley HD, Filiaci V, Markman M, et al. Phase III trial of ifosfamide with or without paclitaxel in advanced uterine carcinosarcoma: a Gynecologic Oncology Group study. J Clin Oncol. 2007; 25: 526-531.

[25] Sutton G, Brunetto VL, Kilgore L, et al. A Phase III trial of ifosfamide with or without cisplatin in carcinosarcoma of the uterus: a Gynecologic Oncology Group study. Gynecol Oncol. 2000; 79: $147-153$.
[26] Kovács P, Sebestyén Z, Farkas R, et al. A pelvic phantom for modeling internal organ motions. Med Dosim. 2011; 36: 250254.

[27] Póti Zs, Katona Cs, Szalai T, et al. Changes in radiotherapy indication for early-stage operated endometrial cancer. Revised staging, predictive factors. Conclusions from our own results. [Változások a korai stádiumú operált méhtestcarcinoma sugárkezelésének indikációjában. Újabb stádiumbeosztás, prediktív tényezők. Tanulságok saját eredményeink alapján.] Orv Hetil. 2016; 157: 1059-1064. [Hungarian]

[28] Rahaman J, Cohen CJ. Radiation therapy for malignant mixed Müllerian tumors. Holland-Frei Cancer Medicine. 6th edn. BC Decker Inc., Hamilton, ON, 2003.

[29] Aghajanian C, Sill MW, Secord AA, et al. Iniparib plus paclitaxel and carboplatin as initial treatment of advanced or recurrent uterine carcinosarcoma: A Gynecologic Oncology Group study. Gynecol Oncol. 2012; 126: 424-427.

[30] Castonguay V, Lheureux S, Welch SA, et al. A phase II trial of sunitinib in women with metastatic or recurrent endometrial carcinoma: a study of the Princess Margaret, Chicago and California Consortia. Gynecol Oncol. 2014; 134: 274-280.

[31] Mackay HJ, Buckanovich RJ, Hirte H, et al. A phase II study single agent of aflibercept (VEGF Trap) in patients with recurrent or metastatic gynecologic carcinosarcomas and uterine leiomyosarcoma. A trial of the Princess Margaret Hospital, Chicago and California Cancer Phase II Consortia. Gynecol Oncol. 2012; 125: 136-140.

[32] Menczer J, Levy T, Piura B, et al. A comparison between different postoperative treatment modalities of uterine carcinosarcoma. Gynecol Oncol. 2005; 97: 166-170.

[33] Einstein MH, Klobocista M, Hou JY, et al. Phase II trial of adjuvant pelvic radiation "sandwiched" between ifosfamide or ifosfamide plus cisplatin in women with uterine carcinosarcoma. Gynecol Oncol. 2012; 124: 26-30.

[34] Wolfson AH, Brady MF, Rocereto T, et al. A Gynecologic Oncology Group randomised phase III trial of whole abdominal irradiation (WAI) vs. cisplatin-ifosfamide and mesna (CIM) as post-surgical therapy in stage I-IV carcinosarcoma (CS) of the uterus. Gynecol Oncol. 2007; 107: 177-185.

(Kalincsák Judit dr., Pécs, Édesanyák útja 17., 7624 e-mail: judit.kalincsak@gmail.com)

\title{
A rendezvények és kongresszusok híranyagának leadása
}

\author{
a lap megjelenése előtt legalább 40 nappal lehetséges, a 6 hetes nyomdai átfutás miatt. \\ Kérjük megrendelőink szíves megértését. \\ A híranyagokat a következő címre kérjük: \\ Orvosi Hetilap titkársága: edit.budai@akademiai.hu \\ Akadémiai Kiadó Zrt.
}

